\title{
Membangun Budaya Guru Pembelajar Melalui Kepemimpinan Visioner
}

\author{
Dedy H. Karwan*, Hasan Hariri, Riswanti Rini
}

FKIP Universitas Lampung, Jl. Prof. Dr. Soemantri Brojonegoro No. 1 Bandar Lampung

*Corresponding e-mail:dhk_bmti@yahoo.co.id

Received: 17 Oktober 2017

Accepted: 1 November 2017

Published: November 2017

Abstract: Building a Learner Teachers Culture through Visionary Leadership. This study aimed to reveal information about the model of building a learner teacher culture through visionary leadership. This qualitative research was conducted in SMPN 2 Bandar Lampung. The research data were obtained through participatory observation, open and structured interviews, Focus Group Discussion (FGD), and documentation study. The results showed that the vision of SMPN 2 Bandar Lampung is appropriate and support the vision of Kemendikbud and meet the good criteria. The provision of intrinsic and extrinsic motivation, visionary leadership of school management, supervision of learner teacher programs, and improvement of modern learning facilities play a role in building the culture of learner teachers through visionary leadership.

Keywords: culture, learner teacher,visionary leadership

\begin{abstract}
Abstrak: Membangun Budaya Guru Pembelajar Melalui Kepemimpinan Visioner. Penelitian ini bertujuan untuk mengungkapkan informasi tentang model membangun budaya guru pembelajar melalui kepemimpinan visioner. Penelitian dengan pendekatan kualitatif ini dilakukan di SMPN 2 Bandar Lampung. Data penelitian diperoleh melalui observasi partisipatif, wawancara terbuka dan terstruktur, Focus Group Discussion (FGD), dan studi dokumentasi. Hasil penelitian menunjukkan bahwa visi SMPN 2 Bandar Lampung sesuai dan mendukung visi Kemendikbud dan memenuhi kriteria baik. Pemberian motivasi instrintik dan ekstrinsik, kepemimpinan visioner dari manajemen sekolah, pendampingan program guru pembelajar, dan peningkatan sarana dan fasilitas pembelajaran modern berperan dalam membangun budaya guru pembelajar melalui kepemimpinan visioner.
\end{abstract}

Kata kunci: budaya, guru pembelajar, kepemimpinan visioner

\section{PENDAHULUAN}

Tuntutan layanan pendidikan kepada masyarakat yang dimanifestasikan dalam mewujudkan sekolah efektifuntuk menghasilkan lulusan yang bermutu, telah melahirkan pemahaman perlu adanya perubahan budaya yang sesuai dengan visi yang dirumuskan pimpinan dengan dilandasi wawasan serta mutu pendidikan umumnya dan mutu pembelajaran khususnya yang harus dilaksanakan oleh guru profesional diawali dengan guru pembelajar untuk perbaikan dan peningkatan mutu sekolah.

Peningkatan mutu sekolah tidak saja ditujukan pada satu komponen pendidikan, tetapi pada seluruh komponen secara proporsional dengan manajemen strategik, berbudaya,untuk menggarap mulai dari perencanaan sampai 
penilaian. Membangun visi sekolah dengan tidak memperhatikan budaya dan sentuhan adalah siasia,dan bahkan budaya yang selama ini berkembang dan diidentifikasikannya sebagai budaya santai menjadi counter-productive terhadap upaya kepemimpinan dalam upaya meningkatkan mutu sekolah. Brameld (1957:19) menyatakan bahwa cara pelaku pendidikan mempersepsi konteks sosial budaya yang mereka miliki merupakan faktor penting yang ikut berpengaruh terhadap mutu pendidikan. Peran guru profesional dapat pula menjamin terciptanya sekolah yang efektif. Oleh karenanya dua pengertian penting dalam penelitian ini adalah budaya menginspirasi perumusan visi dan misi dapat menimbulkan budaya bagi guru menjadi pembelajar untuk mewujudkan guru profesional.

Budaya positif yang berkembang di masyarakat yang bersumber dari keyakinan agama,adat istiadat, norma dan etika, dapat dijadikan nilai sebagai visi yang akan dirumuskan pimpinan,sehingga visi yang dirumuskan dapat menciptakan budaya organisasi melalui nilai-nilai , misi serta tujuan yang ditetapkan dan dibangun bersama. Dengan demikian budaya organisasi akan memberikan arah atau pedoman berperilaku dalam organisasi yang pada gilirannya organisasi tidak dapat semena-mena bertindak dan berperilaku. Sehingga setiap anggota organisasi akan mempunyai kesamaan langkah serta visi didalam melakukan tugas dan tanggung jawabnya, kemudian masing-masing individu dapat meningkatkan fungsinya dan mengembangkan interdependensi antar individu dengan individu dan antar bagian dengan bagian yang lain serta dapat saling melengkapi dalam kegiatan menciptakan kinerja organisasi atau sekolah yang bermutu. Sehingga diharapkan dapat mendorong sumberdaya manusia di dalam sekolah untuk selalu mencapai prestasi kerja atau produktivitas yang lebih baik serta memiliki kepastian karirnya,sehingga mendorong mereka konsisten dengan tugas dan tanggungjawabnya.
Tidaklah berlebihan kalau dikatakan bahwa masa depan masyarakat, bangsa dan negara sebagian besar ditentukan oleh guru. Sehingga agar guru dapat melaksanakan tugasnya dalam memberikan layanan pendidikan atau pembelajaran yang berkualitas kepada peserta didik,maka wajib bagi guru untuk selalu melakukan kegiatan Pengembangan Keprofesian Berkelanjutan (PKB) guna mendukung pengembangan profesi guru sesuai dengan pengembangan ilmu pengetahuan dan teknologi sehingga dalam membangun budaya guru yang terus belajar untuk kebutuhan melaksanakan tugas profesinya (guru pembelajar) dapat terwujud.

Di samping itu, keberadaan kepala sekolah yang visioner sangat dibutuhkan oleh guru karena akan membantu guru membangun budaya belajar. Apalagi saat ini, secara khusus, sekolah negeri sedang menghadapi semakin kompetitif dan dinamis lingkungan pendidikan, serta berbagai tantangan, seperti permintaan masyarakat akan pendidikan yang berkualitas (Kantabutra, 2005, p. 124). Seperti kenyataan dan yang nampak terjadi di lapangan, bahwa budaya guru pembelajar di sekolah belum terbentuk secara baik serta belum berorientasi pada prestasi dan kualitas yang menjadi tuntutan para pemangku kepentingan (stakeholder). Pada sekolahsekolah masih ditemukan budaya uniformitas atau keseragaman dalam melakukan fungsi dan substasi manajerial sehingga perbedaan tuntutan dan visi belum dapat mewujudkan budaya guru pembelajar secara khas dan unik. Surapranata (2015) mengatakan guru pembelajar adalah guru dalam jabatan yang terus menerus meningkatkan kompetensinya untuk mencapai seorang guru profesionalisme. Walaupun berdasarkan hasil uji kompetensi guru sampai dengan tahun 2014 terdapat 192 orang guru dari 2.9 juta lebih yang bernilai amat baik, guru pembelajar harus terus dibangun melalui budaya (Ministry of Education and Culture,2013) serta manajemen sekolah 
melalui kepemimpinan visioner, agar guru memiliki jiwa dan semangat unggul dan kompetitif, sehingga berkinerja efektifmencapai sekolah berkualitas. Pada saat ini sudah terdapat sekolah-sekolah yang sudah maju dan populer sebagai sekolah yang berbudaya dan memiliki reputasi kepemimpinan yang handal,sehingga dapat menunjukan adanya keterkaitan antara budaya dan kepemimpinan. Selanjutnya untuk mengetahui lebih mendalam tentang kajian serta pendapat yang telah diuraikan di atas, maka masih sangat diperlukan penelitian atau kajian tentang upaya membangun guru pembelajar melalui kepemimpian visioner,yang hasilnya diharapkan dapat menjadi masukan peningkatan layanan pendidikan yang bermutu kepada masyarakat khususnya peserta didik.

\section{METODE}

Penelitian ini telah dilakukan pada tahun 2016. Fokus pada penelitian ini yaitu sekolah unggulan serta pada era sebelumnya disebut sekolah berstandar internasional atau era otonomi daerah ditinjau dari kajian kepemimpinan visioner (visionary leadership) dan budaya guru pembelajar, yaitu salah satunya di SMP Negeri 2 Bandar Lampung.

Pendekatan yang dipergunakan dalam penelitian ini adalah dengan menggunakan pendekatan kualitatif, dimana pendekatan kualitatifmerupakan paradigma penelitian untuk mendiskripsikan peristiwa, perilaku orang atau keadaan pada tempat tertentu secara rinci dan mendalam dalam bentuk narasi. Subjek pada penelitian ini adalah pengawas, kepala sekolah, guru, tenaga tata usaha, komite sekolah, orang tua serta peserta didik serta unsur non manusia sebagai data pendukung penelitian yang dipilih dengan purposive sampling, snowball sampling dan triangulation.

Jenis data yang diungkapkan dalam penelitian ini adalah bersifat skematik, narasi dan uraian serta penjelasan data dari informan baik lisan maupun data dokumen yang tertulis, perilaku subyek yang diamati di lapangan juga menjadi data dalam pengumpulan hasil penelitian ini yang selanjutnya dideskripsikan (1) Rekaman audio dan video, dalam melakukan penelitian ini, peneliti merekam wawancara dengan beberapa pihak terkait dengan yang dianggap perlu untuk dikumpuldan data hasil rekaman tersebut dideskripsikan dalam bentuk transkrip wawancara; (2) Catatan Lapangan, dalam membuat catatan di lapangan, peneliti harus melakukan prosedur dengan mencatat seluruh peristiwa yang benar-benar terjadi di lapangan. Hal ini berkisar pada isi catatan lapangan, model dan bentuk catatan lapangan serta proses penulisan catatan lapangan; (3) Dokumentasi; data dikumpulkan dengan melalui berbagai sumber data yang tertulis, baik yang berhubungan dengan masalah kondisi obyektif,juga silsilah dan pendukung data lainnya; (4) Gambar atau Foto; gambar atau Foto merupakan data atau bukti yang tidak dapat diungkapkan dengan kata-kata, namun sangat mendukung kondisi obyektif penelitian berlangsung. Foto-foto untuk artefak budaya guru pembelajar di sekolah.

Untuk memperolah data penelitian yang luas dan mendalam, maka upaya yang dilakukan adalah melalui: (1) Observasi partisipatif; (2) Melakukan wawancara dengan membuat pedoman untuk menjadi acuan dan instrumen yang bersifat terbuka dan terstruktur; (3) Focus group discussion (FGD) atau Forum Diskusi Terpumpun; dan (4) Studi dokumentasi, terutama mengenai akurasi sumber dokumen, bermanfaat sebagai bukti penelitian, sesuai dengan standar kualitatif dan tidak reaktif.

Selanjutnya teknik analisis data yang digunakan adalah deskriptif naratif, yang teknik tersebut menurut Milles dan Hubermen ditetapkan melalui tiga alur yaitu: Reduksi data, Penyajian data serta penarikan kesimpulan atau verifikasi. Dalam penelitian menggunakan metode kualitatif 
dilakukan pengecekan keabsahan data melalui kredibilitas, defendabilitas, konfirmabilitas, tranferabilitas.

Penelitian ini bertujuan untuk mengungkapkan informasi tentang hal-hal berikut ini. Pertama, profil kepemimpinan visioner di SMPN 2 Bandar Lampung, membahas visi SMPN 2 Bandar Lampung, dilihat kesesuaian dengan visi kementerian. Jika visi tidak sesuai dengan visi kementerian, ketercapaian visi kementerian akan sulit untuk dicapai. Kedua, mekanisme Kepala Sekolah menciptakan dan merumuskan serta mengimplementasikan visi bersama, sangatlah penting visi dibuat sedemikian rupa sehingga memenuhi kriteria visi yang baik. Untuk mengamati apakah karakteristik visi sesuai dengan tujuh kriteria para ahli sebagaimana dipaparkan di bawah ini. Ketujuh kriteria itu sebagaimana dirangkum oleh (Kantabutra, 2005) adalah sebagai berikut: brevity (keringkasan), clarity (kejelasan), future orientation (orientasi masa depan), stability (stabilitas), challenge (tantangan), abstractness (keabstrakan), desirability or ability to inspire (keinginan atau kemampuan untuk menginspirasi). Ketujuh kriteria tersebut yaitu: (1) Brevity. Sebuah visi harus singkat, tetapi singkatnya harus tidak menolak upaya untuk menyatakan visi secara pasti. Sebuah visi dapat dikatakan jelas, jika memiliki 10 sampai 12 kata-kata dan dapat dikomunikasikan dalam periode waktu yang singkat, maksimal dalam 3 sampai 5 menit; (2) Clarity. Visi harus jelas dan tepat sedemikian rupa sehingga dipahami dan diterima. Kejelasan membuat tujuan menyeluruh yang dapat dimengerti oleh setiap orang; (3) Future orientation. Sebuah visi harus fokus pada perspektif jangka panjang organisasi dan lingkungan di mana visi itu berfungsi. Ini harus memandu organisasi jauh ke masa depan; (4) Stability. Sebuah visi harus umum dan cukup abstrak agar tidak terpengaruh oleh perubahan- perubahan di pasar atau dalam teknologi; (5) Challenge. Sebuah visi harus memotivasi orangorang untuk bekerja menuju hasil yang diinginkan. Visi menantang orang-orang untuk melakukan yang terbaik; (6) Abstractness. Sebuah visi harus mewakili gambaran umum sebagai lawan prestasi tertentu. Hal ini tidak sempit, bukan tujuan satu waktu yang dapat dipenuhi, kemudian dibuang; (7) Desirability or ability to inspire. Sebuah visi harus mewakili ideal yang layak bekerja menuju untuk pengikut. Jika pengikut tidak melihat visi sebagai tujuan yang menarik, mereka tidak akan pernah berkomitmen untuk mencapainya. Ketiga, usaha yang dilakukan Sekolah dalam membangun budaya guru pembelajar. Keempat, langkah-langkah yang ditempuh sekolah dalam mengimplementasikan kepemimpinan visioner dalam membangun budaya guru pembelajar. Kelima, model membangun budaya guru pembelajar melalui kepemimpinan visioner.

\section{HASIL DAN PEMBAHASAN}

Berdasarkan data yang diperoleh dari dokumen profil sekolah, maka diperoleh Visi Sekolah adalah: Unggul, Kompetitif dan Kolaboratif di Era Global berlandaskan Iman dan Takwa. Sedangkan untuk mengukur ketercapaian visi, sekolah telah menetapkan indikatorindikatornya yaitu (1) Terwujudnya pendidikan yang bermutu, efisien dan relevan di era global; (2) Terwujudnya manajemen sekolah yang transparan,akuntable,efektif dan partisipatif; (3) Unggul dalam sumberdaya manusia sekolah,sarana dan prasarana sekolah serta fasilitas sekolah; (4) Unggul dalam prestasi akademik, yang meliputi nilai ujian nasional, berbagai lomba mata pelajaran (olimpiade mata pelajara pada tingkat nasional dan internasional); (5) Unggul dalam prestasi non akademik yang meliputi,lomba kegiatan ekstra kurikuler serta imtaq dan budi pekerti. 
Sedangkan untuk mencapai visi sekolah telah ditetapkan misi sebagai berikut yaitu (1) Mewujudkan lulusan yang berprestasi dan mampu bersaing ditingkat nasional maupun Internasional; (2) Mewujudkan siswa dengan kemampuan non akademik yang mampu bersaing ditingkat nasional maupun internasional; (3) Mewujudkan lulusan yang cerdas, kompetitif, cinta tanah air, santun dan bertaqwa; (4) Mewujudkan perangkat kurikulum yang lengkap, kreatif, inovatif dan menyenangkan; (5) Mewujudkan proses pembelajaran yang aktif kreatif, efektif, inovatif dan menyenangkan melalui pendekatan akademik; (6) Mewujudkan fasilitas sekolah yang lengkan dan relevan dan berwawasan kedepan; (7) Mewujudkan pendidik dan tenaga kependidikan yang mampu memiliki komitmen dan kompetensi tinggi; (8) Mewujudkan manajemen berbasis sekolah (MBS) yang tangguh; (9) Mewujudkan sistem penilaian yang autentik proses dan hasil belajar yang akuntabel; (10) Mewujudkan pembimbingan yang memadai,wajar dan adil sesuai dengan tuntutan pendidikan; (11) Mewujudkan jalinan kerjasama dengan sekolah dan institusi lain didalam dan diluar negeri; (12) Mewujudkan sekolah yang inovatif, kreatif, dinamis dan berwawasan internasional; dan (13) Mewujudkan lingkungan sekolah yang nyaman,aman, asri, bersih dan sehat.

Manajemen sekolah dalam perumusan visi sekolah visioner

Visi merupakan tujuan akhir sekolah, tujuan jangka panjang organisasi. Visi telah dianggap sebagai komponen penting dari kepemimpinan efektif selama lebih dari 20 tahun (Bush, 2015). Visi SMPN 2 Bandar Lampung adalah unggul, kompetitif, dan kolaboratif di era global berlandaskan iman dan taqwa. Sedangkan visi kemendikbud adalah terbentuknya insan serta ekosistem Pendidikan dan Kebudayaan yang berkarakter dengan dilandasi semangat gotong royong. Baik visi SMPN 2 Bandar Lampung maupun visi Kemendikbud yang utama adalah menekankan pendidikan karakter untuk membentuk insan yang taqwa, bahkan Kemendikbud tidak hanya menekankan pada insan berkarakter tetapi luas lagi ekosistem yang berkarakter. Oleh karena itu, langkah utama untuk mencapai visi tersebut adalah salah satunya pendidikan di Indonesia harus secara terus menerus menanamkan nilai-nilai karakter anak yang embedded pada setiap mata pelajaran. Perencanaan dan diikuti pelaksanaan penanaman nilai-nilai karakter siswa di sekolah mutlak dilakukan untuk mendukung ketercapaian misi sekolah dan pada akhirnya visi Kemendikbud.

Dalam hal perencanaan, penanaman nilainilai karakter harus direncanakan dengan sebaikbaiknya, karena perencanaan yang tidak baik akan mengarah kepada pencapaian tujuan pendidikan secara tidak efektif. Perenacaan penanaman nilai-nilai karakter ini mesti berdasarkan pedoman yang telah ditetapkan Kemendikbud. Berikut merupakan tahapan yang bisa dilakukan dalam perencanaan untuk menanamkan nilai-nilai pendidikan karakter di sekolah. (1) Tahap 1: Sosialisasi dan Pelatihan. Sosialisasi kepada kepala sekolah dan kurikulum melalui workshop yang dilakukan Dinas Pendidikan oleh tim Pusat Kurikulum dengan penekanan kepada tujuan pendidikan karakter, misalnya menyampaikan tentang konsep pendidikan karakter di sekolah. Setelah kegiatan workshop selanjutnya diikuti dengan pelatihan kepada guru-guru tentang bagaimana cara mengembangkat perangkat pembelajaran, misalnya silabus, RPP dan perangkat pembelajaran yang lain yang memuat nilai-nilai karakter. Tujuan utama pelatihan adalah untuk menyamakan persepsi terutama antarguru tentang proses implementasi nilai-nilai karakter di sekolah misalnya pada saat proses pembelajaran di kelas. (2) Tahap 2: Pengembangan kurikulum. Pengembangan kurikulum memuat nilai-nilai karakter dilakukan oleh bagian kurikulum; dan 
(3) Tahap 3: Menetapkan shared rules of the game atau peraturan yang disepakati bersama. Peraturan sekolah harus secara pasti diketahui siswa, hasil kepsepakatan antara kepala sekolah, guru dan siswa. Untuk itu, siswa bisa difasilitasi dengan buku saku siswa.

Ketiga tahap ini selanjutnya diikuti tahap pelaksanaan penanaman nilai-nilai karakter pada setiap pelajaran di sekolah.

Dalam hal pelaksanaan, implementasi nilainilai pendidikan karakter dilakukan berbagai cara misalnya melalui pembelajaran, pembiasaan, dan selanjutnya menjadi budaya sekolah. Implementasi nilai-nilai pendidikan karakter di SMPN 2 dimulai saat siswa hadir di sekolah. Siswa hadir paling tidak 5 menit sebelum bel masuk berbunyi. Siswa yang terlambat lebih dari 15 menit idealnya mendapatkan sanksi berupa pengurangan point dan tidak diperbolehkan mengikuti kegiatan pembelajaran pada jam pertama sesuai dengan peraturan yang tertulis pada buku siswa. Tapi bisa saja, misalnya, siswa masih diberikan toleransi 3 kali oleh guru mata pelajaran yang bersangkutan dan masih boleh mengikuti jam pelajaran pertama.

Cara-cara lain penanaman nilai-nilai karakter harus dilakukan secara konsisten di sekolah sesuai dengan rules of the game yang sudah disepakati bersama antara kepala sekolah, guru, dan siswa. Reward system baik sekali untuk diaplikasikan dalam penanaman nilai-nilai karakter di sekolah. Inilah bagaimana sekolah mesti melakukan perencanaan dan pelaksanaan penanaman nilai-nilai karakter di sekolah sesuai dengan visi sekolah untuk mendukung visi kementerian.

Selanjutnya, kita akan melihat apakah visi SMPN 2 Bandar Lampung memenuhi tujuh kriteria atau atribut visi yang baik. Visi SMPN 2 Bandar Lampung: "Unggul, kompetitif, dan kolaboratif di era global berlandaskan iman dan taqwa." Visi ini dinilai apakah memenuhi tujuh atribut atau kriteria sebagai visi yang baik. (a) Kriteria pertama: Brevity/ Keringkasan. Visi tersebut bernas dan terdiri dari dari 11 kata, sangat ringkas. Dengan demikian, visi SMPN 2 Bandar Lampung dikategorikan visi yang ringkas, tetapi mampu memungkinakn upaya untuk menyatakan visi secara pasti, dan . dapat dikomunikasikan dalam periode waktu yang singkat; (b) Kriteria kedua: Clarity/Kejelasan. Visi SMPN 2 Bandar Lampung memenuhi kriteria ini. Walaupun dengan 11 kata, visi tersebut jelas dan tepat sehingga dapat dipahami dan diterima. Kejelasan membuat tujuan menyeluruh dan dapat dimengerti oleh setiap orang; (c) Kriteria ketiga: Future orientation/ Orientasi masa depan. Visi SMPN 2 Bandar Lampung melihat masa depan dengan realistic. Visi tersebut fokus pada perspektif jangka panjang organisasi dan lingkungan di mana visi itu berfungsi, dan dapat memandu organisasi jauh ke masa depan. Dengan kata kata lin, visi tersebut berorientasi pada masa depan organisasi sekolah tersebut; (d) Kriteria keempat: Stability/ Stabilitas. Visi SMPN Bandar Lampung dapat dikatakan stabil karena tidak dipengaruhi perubahan-perubahan pasar. Iman dan taqwa yang ingin dicapai sampai kapanpun tidak akan berubah karena harus demikian adanya sebagai makhluk Yang Mahakuasa. Visi tersebut bersifat umum dan berlaku secara universal, dan disamping itu juga cukup abstrak agar tidak terpengaruh oleh perubahan-perubahan di era globalisasi; (e) Kriteria kelima: Challenge/ Tantangan. Visi SMPN 2 Bandar Lampung mampu memotivasi orang-orang untuk bekerja menuju hasil yang diinginkan. Visi tersebut dapat dikatakan menantang para guru untuk melakukan yang terbaik sesuai dengan kemampuan mereka; (f) Kriteria keenam: Abstractness/Keabstrakan. Visi SMPN 2 Bandar Lampung, sebagaimana dikatakan sebelumnya, bersifat umum dan berlaku secara universal, yaitu mewakili 
gambaran umum sebagai lawan gambaran sepsifik yang dapat dicapai dalam waktu singkat. Dengan demikian, visi dapat dicapai dalam waktu yang lama yang telah ditetapkan, dan tidak dapat dicapai dalam waktu singkat sehinga mengindari visi dari keusangan dalam perjalanan; dan (g) Kriteria ketujuh: Desirability or ability to inspire/ Keinginan atau kemampuan untuk menginspirasi. Visi SMPN 2 Bandar Lampung mampu menginspirasi setiap orang, termasuk guru-guru SMPN 2 Bandar Lampung. Visi tersebut mewakili ideal yang layak bagi pengikut. Dalam hal ini, pengikut melihat visi sebagai tujuan yang menarik sehingga mereka berkomitment untuk mencapainya. Secara singkat dapat dikatakan bahwa: Pertama, visi SMPN 2 Bandar Lampung sesuai dan mendukung visi Kemendikbud, terutama berfokus kepada pendidikan karakter menuju iman dan taqwa. Kedua, visi SMPN2 Bandar Lampung memenuhi tujuh kriteria/atribut visi yang baik: brevity (keringkasan), clarity (kejelasan), future orientation (orientasi masa depan), stability (stabilitas), challenge (tantangan), abstractness (keabstrakan), desirability or ability to inspire (keinginan atau kemampuan untuk menginspirasi).

Manajemen Sekolah melalui Kepemimpinan Visioner dalam Membangun Budaya Guru Pembelajar

Dalam membangun budaya guru profesional selain harus mengacu pada visi pemerintah dan tuntutan pendidikan abad 21 yang berfokus pada tuntutan peserta didik juga harus memperhatikan syarat menjadi guru di Indonesia sesuai regulasi dan peraturan perundangundangan yang berlaku untuk menyiapkan guru profesional dan kompeten. Guru Profesional wajib memiliki kualifikasi akademik, kompetensi, sertifikat pendidik, sehat jasmani dan rohani, serta memiliki kemampuan untuk mewujudkan tujuan pendidikan nasional sesuai Pasal 8 UU14/2005 Guru \& Dosen.
Kompetensi guru yang meliputi kompetensi pedagogik, kompetensi kepribadian, kompetensi sosial, dan kompetensi profesional yang diperoleh melalui pendidikan profesi sesuai Pasal $10 \mathrm{UU}$ N0. 14/2005 Guru \& Dosen. Terhitung sejak 30 Desember 2005, Standar Pendidikan Guru harus memenuhi Kualifikasi Akademik, Kualifikasi akademik diperoleh melalui pendidikan tinggi program sarjana atau program diploma empat sesuai Pasal 9 UU No. 14/2005 Guru \& Dosen. Dalam membangun budaya guru pembelajar di SMP Negeri 2 Bandar Lampung tetap dan selalu berpedoman serta berorientasi pada kebutuhan pembelajaran dalam membangun dan mengembangkan potensi siswa seuai tujuan sekolah serta sejalan dengan visi sekolah yang telah ditetapkan, yaitu (1) Membangun rasa percaya diri pada siswa. Kepercayaan diri merupakan keyakinan seseorang akan kemampuan yang dimiliki untuk menampilkan secara baik dihadapan orang lain, apakah tingkat kepercayaan diri sesorang itu bakat, kecerdasan atau kualitas mental yang pencapaiannya dihasilkan dari proses pendidikan atau pemberdayaan sehingga setiap orang bisa dilatih dan dididik untuk menjadi lebih percaya diri sesuai dengan keadaannya; (2) Membangun daya ingat siswa. Guna memudahkan pemahaman tentang pendayagunaan daya ingat, guru perlu memahami dan mengetahui cara kerjanya; (3) Membangun motivasi siswa. Inti dari motivasi merupakan kondisi psikologiss yang mendorong sesorang untuk melakukan sesuatu. Dalam kegiatan belajar, motivasi sangat diperlukan karena sesorang yang tidak mempunyai motivasi dalam belajar tidak mungkin melakukan aktivitas belajar dengan efektif; (4) Membangun komunikasi dan empati. Guru dan siswa merupakan bagian dari sisten pendidikan yang membutuhkan tingkat interaksi yang tinggi. Oleh karenanya kedua subjek pendidikan tersebut perlu menjalin komunikasi positif, dengan demikian guru harus memiliki sof skill yang dapat menghindarkan kesalahpahaman 
atau kesalah pengertian yang dapat menyebabkan terjadinya persoalan pendidikan. (5) Membangun kreativitas dalam pembelajaran. Kreativitas dapat diartikan sebagai kemampuan berfikir mengenai sesuatu dengan cara yang baru dan langka serta menghasilkan penyelesaian yang unik; (6) Membangun dan memahami keberagaman kecerdasan di kelas. Dalam membangun dan memahami keberagaman kecerdasan peserrta didik dalam membangun budaya guru pembelajar maka dikembangkan pendapat Howard Gardner (2001) yang terdiri dari 7 (tujuh) komponen kecerdasan dan pendapat Thomas Amstrong (2004) yang terdiri dari 8 (delapan kecerdasan). Namun kedua pendapat tersebut dirangkum dan disesuaikan dengan konsep pengembangan kecerdasan yang dirumuskan oleh Kementerian Pendidikan dan kebudayaan yaitu Kecerdasan spirituan, kecerdasan emotional/ sosial, kecerdasan intelektual dan kecerdasan kinestetik secara komprehensif dan kompetitif; (7) Mengembangkan model pembelajaran kecerdasan ganda disekolah. Dalam mengembangkan model pembelajaran ganda disekolah, ada beberapa cara yang dapat digunakan, yaitu (a) Meminta batuan teman yang ahli; (b) Meminta bantuan siswa; dan (c) Menggunakan teknologi yang dikuasai.

Hasil Kepemimpinan Visioner dalam membangun Budaya Guru Pembelajar

Berikut adalah data pendukung dalam penelitian ini, yaitu luas lahan SMP Negeri 2 Bandar Lampung 15.050 meter persegi dengan luas tanah yang terbangun 11.000 meter persegi.
Sedangkan pada pertengahan tahun 2016 keadaan atau jumlah pegawai yang terdiri dari tenaga administrasi/Tata Usaha, laboran, kebersihan dan pejaga sekolah sebanyak 21 orang. Sementara itu data guru dan peserta didik SMP Negeri 2 ditunjukkan pada Tabel 1 dan 2 berikut.

\section{Tabel 1. Keadaan Guru}

\begin{tabular}{ccccc}
\hline Jenis Kelamin & S-2 & S-1 & D-2 & Jumlah \\
\hline Laki-laki & 9 & 10 & 1 & 20 \\
Perempuan & 15 & 16 & - & 31 \\
\hline Jumlah & 24 & 26 & 1 & 51 \\
\hline
\end{tabular}

Tabel 2. Keadaan Peserta Didik dalam 5 Tahun

\begin{tabular}{lcccc}
\hline \multirow{2}{*}{ Th. Ajaran } & \multicolumn{3}{c}{ Kelas } & Jumlah \\
\cline { 2 - 4 } & VII & VIII & IX & \\
\hline $2012 / 2013$ & 163 & 184 & 141 & 488 \\
$2013 / 2014$ & 331 & 178 & 165 & 671 \\
$2014 / 2015$ & 308 & 317 & 168 & 793 \\
$2015 / 2016$ & 255 & 312 & 294 & 861 \\
$2016 / 2017$ & 308 & 255 & 277 & 840 \\
\hline
\end{tabular}

Sejak 5 tahun terakhir Sekolah Menengah Pertama (SMP) Negeri 2 Bandar Lampung telah meluluskan sebanyak 988 siswa dengan jumlah lulusan yang setiap tahun rata-rata meningkat mulai dari 141 dan pada tahun ajaran 2015/2016 mencapai 334 siswa.

Selanjutnya data prestasi sekolah yang diperoleh berdasarkan nilai ujian akhir nasional dan ujian akhir sekolah serta sarana dan fasilitas penunjang pembelajaran dapat dilihat seperti pada Tabel 3 dan 4 berikut.

Tabel 3. Prestasi Akademik Sekolah

\begin{tabular}{lcccccc}
\hline \multirow{2}{*}{ Tahun Ajaran } & \multicolumn{7}{c}{ Rata - Rata Nilai Ujian Akhir Nasional } \\
\cline { 2 - 7 } & B.Indonesia & Matematika & B.Ingris & IPA & Jumlah & Rata-rata \\
\hline $2011 / 2012$ & 9,25 & 9,18 & 8,86 & 9,21 & 36,50 & 9,13 \\
$2012 / 2013$ & 8,65 & 8,84 & 8,69 & 8,38 & 34,56 & 8,64 \\
$2013 / 2014$ & 8,53 & 9,63 & 8,99 & 9,30 & 36,45 & 9,11 \\
$2014 / 2015$ & 8,72 & 8,61 & 8,89 & 9,16 & 35,37 & 8,84 \\
$2015 / 2016$ & 8,67 & 7,18 & 8,41 & 7,59 & 31,85 & 7,96 \\
\hline
\end{tabular}


Tabel 4. Koleksi Buku Perpustakaan

\begin{tabular}{clccc}
\hline No. & \multicolumn{1}{c}{ Jenis } & Jumlah & \multicolumn{2}{c}{ Kondisi } \\
\cline { 4 - 5 } 1 & $\begin{array}{l}\text { Buku siswa pelajaran (semua mata } \\
\text { pelajaran) }\end{array}$ & 32.127 & 19.810 & 12.317 \\
$\begin{array}{l}\text { Buku bacaan (misalnya: novel, buku } \\
2\end{array}$ & $\begin{array}{l}\text { ilmu pengetahuan dan teknologi, } \\
\text { dsb.) }\end{array}$ & 9.939 & 786 & 9.153 \\
3 & $\begin{array}{l}\text { Buku referensi (misalnya: kamus, } \\
\text { ensiklopedia, dsb.) }\end{array}$ & 1.476 & 28 & 2.216 \\
4 & Jurnal/majalah/surat kabar & 215 & - & 215 \\
\hline \multicolumn{1}{c}{ Total } & 44.525 & 20.624 & 23.901 \\
\hline
\end{tabular}

Dalam rangka meningkatkan mutu layanan kepada peserta didik, SMP Negeri 2 Bandar Lampung sejak 5 tahun terakhir terus berupaya membangun kultur atau budaya guru pembelajar melalui berbagai program dan kegiatan baik yang dilakukan sesuai kreativitas dan inovasi guru secara bersama-sama dalam komunitas pendidik serta secara individu yang dilakukan disekolah maupun berdasarkan berbagai program pemerintah pusat dan daerah.

Berikut data bagaimana sekolah dan manajemen sekolah membangun budaya Guru sebagai pembelajar sepanjang hayat atau yang dapat disebut pengembangan profesionalisme berkelanjutan untuk mencapai prestasi sekolah atau sekolah efektif dalam mewujudkan visi sekolah dapat dilihat pada Tabel 5 yang menunjukkan program peningkatan mutu guru melalui program guru pembelajar yang disiapkan oleh pemerintah pusat dan daerah berdasarkan hasil Uji Kompetensi Guru (UKG) tahun 2015.

Tabel 5. Program Guru Pembelajar

\begin{tabular}{|c|c|c|}
\hline \multirow{2}{*}{ Program } & \multicolumn{2}{|c|}{$\begin{array}{c}\text { Kualifikasi Pendidikan } \\
\text { Guru }\end{array}$} \\
\hline & $\begin{array}{l}\text { Diploma } \\
\text { \& S1 }\end{array}$ & S2 \\
\hline Tatap Muka & - & - \\
\hline $\begin{array}{l}\text { Kombinasi } \\
\text { (Blended System) }\end{array}$ & 27 & 24 \\
\hline Jarak Jauh (Online) & - & - \\
\hline
\end{tabular}

Hasil Kepemimpinan Visioner dalam Membangun Budaya Guru Pembelajar

Hasil penelitian yang diperoleh dari observasi dokumen rencana kerja sekolah dan kegiatan penunjang siswa di sekolah yaitu pada Tabel 1-5, hasil Forum Group Discussion (FGD) 1, FGD 2 dan wawancara kepada tim manajemen sekolah, diketahui bahwa dalam meningkatkan profesionalisme guru melalui kegiatan guru pempelajar dapat diuraikan sebagai berikut; (1) Dalam kegiatan peningkatan kompetensi peofesionalnya guru menyusun program kerja mengacu pada visi sekolah dan Keterampilan abad 21 yang dibutuhkan setiap peserta didik yang dituangkan dalam kurikulum nasional yaitu: (a) Kualitas Karakter, yaitu bagaimana siswa beradaptasi pada lingkungan yang dinamis dengan mengajarkan perilaku dan etika kehidupan dengan materi (1) Nilai Pancasila; (2) Ketaqwaan; (3) Integritas; (4) Rasa ingin tahu; (5) Inisiatif; (6) Kegigihan; (7) Kemampuan adaptasi; (8) Kepemimpinan; dan (9) Kesadaran sosial \& budaya. (b) Literasi Dasar, yakni bagaimana siswa menerapkan keterampilan dasar sehari- hari dengan mengajarkan : (1) Literasi baca tulis; (2)Literasi berhitung; (3) Literasi sains; (4) Literasi financial; dan (5) Literasi budaya dan kewarganegaraan. (c) Kompetensi, dengan cara bagaimana siswa memecahkan masalah kompleks dengan cara kerja; (a) Berpikir kritis; 
(b) Kreativitas; (c) Komunikasi; dan (d) Kolaborasi.

Dengan memperhatikan data hasil penelitian tentang bagaimana kepala sekolah dan jajaran dewan guru dalam memberikan layanan kepada peserta didik, termasuk upaya yang dilakukan oleh para guru yang didukung oleh fasilitas perpustakaan, prestasi yang diperoleh sekolah selama 5 tahun terakhir, prestasi guru dari sisi kualifikasinya yang dicapai dengan kerja sama semua komponen sekolah melalui manajemen berbasis sekolah,sarana dan fasilitas yang memadai serta kerjasama yang baik dengan stakeholder sesuai dengan visi sekolah, maka dapat disimpulkan bahwa kepemimpinan visioner secara significan dan bertahap telah dapat membangun budaya guru pembelajar di sekolah. Namun demikian untuk memacu akselerasi dan keberlanjutan (sustainibility) program guru pembelajar diperlukan motivasi internal dan eksternal dalam membangun budaya atau kultur sekolah yang kondusif melalui kepemimpinan visioner. Berikut ini adalah model membangun budaya guru pembelajar melalui kepemimpinan visioner (Gambar 1).

\section{MEMBANGUN BUDAYA GURU PEMBELAJAR MELALUI KEPEMIMPINAN VISIONER}

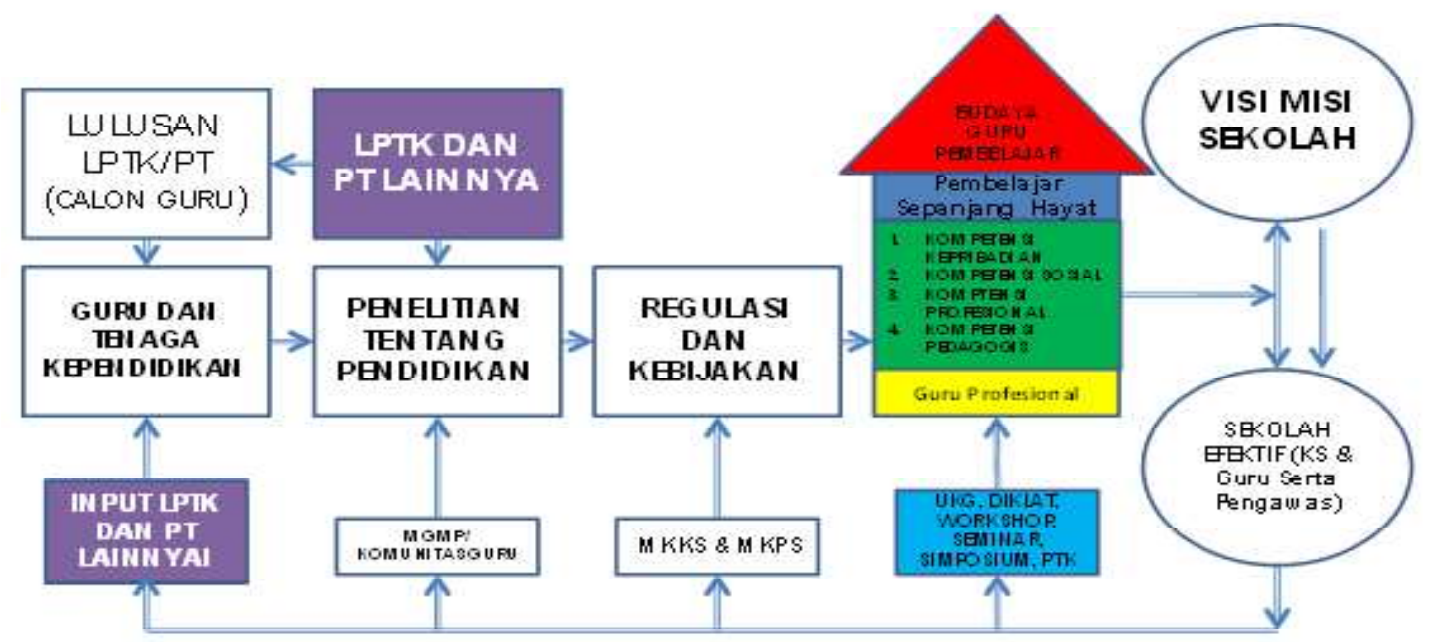

Gambar 1. Skema/Model Membengun Budaya Guru Pembelajar

\section{SIMPULAN}

Berdasarkan pembahasan hasil penelitian dapat disimpulkan sebagai berikut. (1) Visi dan penjabaran misi sekolah masih perlu disesuaikan dengan keadaan awal sekolah dan ketentuan kementerian dalam hal ini bahwa visi sekolah harus sinkron dengan visi Kemendikbud; (2) Visi SMPN 2 Bandar Lampung sesuai dan mendukung visi Kemendikbud, terutama berfokus kepada pendidikan karakter menuju iman dan taqwa; (3) Visi SMPN 2 Bandar Lampung memenuhi tujuh kriteria/atribut visiyang baik: brevity, clarity, future orientation, stability, challenge, abstractness, desirability or ability to inspire; (4) Dalam membangun budaya guru pembelajar harus terus diberikan 
motivasi instrintik maupun motivasi eksternal agar dapat menjamin keberlangsungan peningkatanan mutu proses pembelajaran dalam menuju dan mencapai sekolah efektif; dan (5) Kepemimpinan visioner dari manajemen sekolah harus terus memacu dan mendampingi program guru pembelajar dan terus meningkatkan sarana dan fasilitas pembelajaran modern seperti perangkat ICT serta kegiatan penunjang ekstrakurikuler.

\section{DAFTAR RUJUKAN}

Brameld, T. (1957). Cultural Foundations of Education: An Interdisciplinary Exploration, New York: Harper \& Brothers.

Bush, T. 2015.The Problem with Vision. Editorial. Educational Management Administration \& Leadership, 43(2): 175-176.
Kantabutra, S. (2005). Improving public school performance through vision-based leadership. Asia Pacific Education Review, 6(2), 124-136.

Ministry ofEducation and Culture. (2013). Overview of the education sector in Indonesia 2012 - Achievements and challenges. Jakarta: Ministry of Education and Culture of the Republic of Indonesia.

Surapranata, Sumarna. (2015, 11 November). Satu Direktorat Demi Memuliakan Guru. Diakses padatanggal 19 April 2016 dari http://www.republika.co.id/ berita/koran/wawasan/15/11/11/ nxnb4t1-sumarna-surapranata-direkturj e n d e r a l - g u r u - d a n - t e n a g a kependidikan-satu-direktorat-demimemuliakan-guru. 